\title{
Analysis of the Involvement and Impressions of the Local Community on the Tourism Development of llocos Norte
}

\author{
Cherie B. Orpia ${ }^{1}$ \\ ${ }^{1}$ Mariano Marcos State University, Batac City, Ilocos Norte, Philippines
}

\begin{abstract}
Tourism development is not possible without the involvement of the local community in various development stage and tourism activities. They can be involved right from planning, construction, operation, and promotion activities. It generates investment, foreign exchange and employment to the locals. This study sought how the local community is involved and what are their impressions in Ilocos Norte's Tourism developments. It also sought to determine the demographic qualities differentiates against tourism development involvement and their impressions. The study used non-probability convenience sampling in various towns in Ilocos Norte. Questionnaire type of survey and unstructured interviews were employed to the locals and to the local government units. Local residents perceive the tourism activities to provide employment opportunities, income, foreign exchange, and promote cultural heritage. Very few perceive to be a contributor to pollution and depletion of natural resources.. Most people have an impression that it has improved their way of life thru more access to their town, business opportunities, and more infrastructure. However, most of them has an impression that cleanliness and safety has gotten worse. Most people like to participate in tourism activities thru investment, employment and planning.
\end{abstract}

\section{Introduction}

The state recognizes the tourism industry as an indispensable element of the national economy and an industry of national interest and importance. It is an engine of socio-economic growth and cultural affirmation to generate investment, foreign exchange and employment, and an engine to mold and enhance our national pride for all Filipinos. Furthermore, it is dedicated in to developing environmentally sound and community participatory tourism programs and development, enlisting the participations of the local communities.

Tourism development is a significant aspect in the tourism industry. It calls for the identification of geographical areas with potential tourism value and creating plans which the government via the Department of Tourism is responsible in this undertaking. The Department is also responsible into analyzing the socio-economic impact of tourism to the affected local communities; Formulation and enforcement of standards for the operations and maintenance of each development, prescribing the minimum levels of operating quality and efficiency with the local and international standards by creating rules and regulation on each tourism developments being established; And to evaluate tourism developments in accordance with the set standards. 
The province of Ilocos Norte for the past half decade, has been very aggressive in promoting and packaging Ilocos Norte as a major tourist destination. Huge budget allocations has been made do develop tourist sites and infrastructures within the vicinity. To the locals this would mean changes in how the live within their communities. Positive or negative, it would mean more cash inflows to the locality, more jobs, but it would also mean the negative aspects of having a lot of people in the community and this would mean possible problems on peace and order garbage disposal, destruction of environment among others.

This study therefore seeks how the local community is involved and what are their impressions in Ilocos Norte's Tourism developments. It also seeks to determine the demographic qualities differentiates against tourism development involvement and their impressions.

\section{Related Studies}

According to Muganda [1] there are various ways through which communities can be involved in the tourism industry so as to attract their support and participation which in turn enhance the development of the industry. He focused on the two factors namely, the involvement in the tourism decisionmaking process and the employment opportunities.

Tosun, [2] suggested that community participation via decision making is crucial determinant to ensure that the benefits local communities get from tourism are guaranteed, and their lifestyle and values are respected. While, employment opportunities is another way to involve and attract community participation and ultimately support in tourism development. Tosun [3] then stressed that the community participation through working in the tourism industry has been recognized to help local communities not only to support development of the industry but also to receive more than economic benefits.

It is quite given than it is inevitable that the community is involved in planning and development due to the nature of tourism - which is pervasive, that uses the community as a resource, sells as a product and in the process, affects the life of everyone [4].

The current situation in Ilocos Norte is that individual town has its own strategy, cub cultures and interests. The tourism program now of the province seems to encompass all of these to form a provincial tourism program that would be an assortment of activities and interests. Murphy and Murphy [5] might refer to this as the community approach to tourism development as it integrates interest of all stakeholders, residents included.

This program would apparently address the issue of benefits and costs for individuals and community. It may be ordinary for them to see local sights, food interests but then tourism and outsiders might get interested as these are unusual to them, therefore the local would start to appreciate these local aspects of their community and therefore would realize the revenues [6].

\section{Data and Methodology}

Data are gathered came from the selected municipalities and cities of Ilocos Norte that possess many tourism related developments, namely, Paoay, Laoag, Bangui, Currimao, Burgos and Pagudpud. Questionnaires were floated from the month of August to September, 2013. 


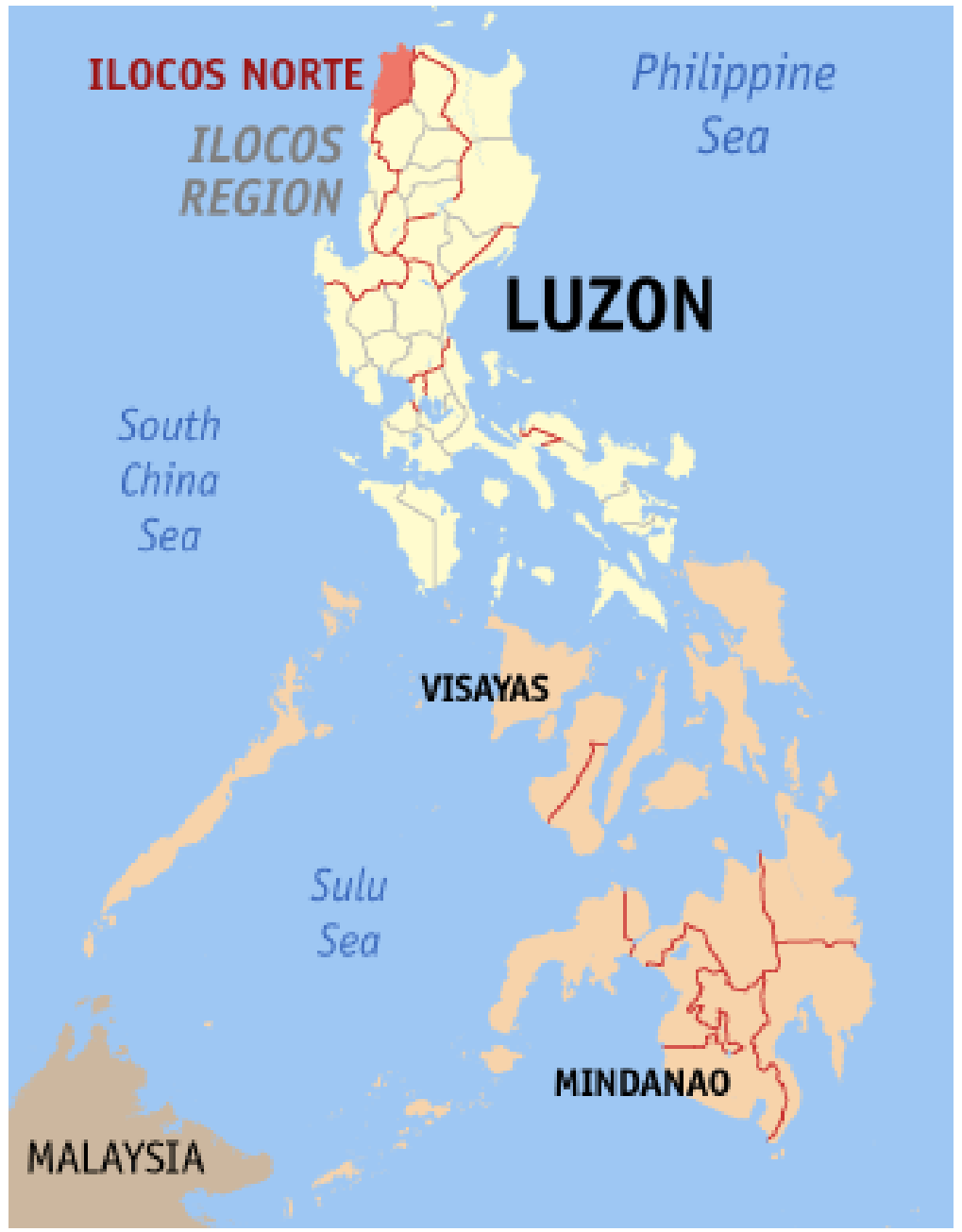

Figure 1. Location of the Study.

The study used non-probability convenience sampling of 100 residents per municipality because of ease of implementation. Questionnaire type of survey and unstructured interviews were employed to the locals and to the local government units. Date are analyzed according to basic statistical descriptives and statistical analysis of the data using Mann-Whitney $U$ and Kruskal-Wallis test to see if the various tourism impacts are the same on various socio-economic factors.

\section{Results and Discussion}

The perception of the locals on tourism development were gathered and summarized on a horizontal bar graph in figure 2. Is divided in terms of respondents who answered "strongly disagree", "disagree", "neither"," agree", and "strongly agree" Most locals agree that tourism development has a positive impact to community. For the environmental aspect, the locals see tourism to be encouraging environmental awareness. For socio cultural, the locals perceive the impacts on all aspects (conserves archeological and historical sites, encourages cultural activities, promotes cross cultural exchange). For economic aspects, the locals perceive the tourism development to improve infrastructures, improves accessibility, generates foreign exchange, generates income and provides employment. 
Figure 3 shows varied tourism impacts for the past five years based on the perception of locals whether it has gotten better or worse or nothing changed. For the socio-cultural and economic impacts, the locals see it as it has gotten better. For the environmental impacts, most locals sees that it gotten better although there is a good percentage that see that pollution has not changed or it has gotten even worse. Several local also make mention of the cleanliness has gotten worse

The locals are involved in several ways on tourism industry and development of their locality. Plenty of them agrees and strongly agrees that the locals are participating in seminars, responding to surveys, planning, as an employee, and as an investor.

Table 1. Sociodemographic Profile of Respondents

\begin{tabular}{llll}
\hline Socio Demographic Profile & & Count & Percentage \\
\hline Gender & Male & 277 & 46 \\
& Female & 323 & 54 \\
\hline Age & $18-30$ & 271 & 45 \\
& $31-55$ & 273 & 46 \\
& $56-80$ & 51 & 9 \\
& Undefined & 5 & 1 \\
\hline Marital Status & Single & 277 & 45.2 \\
& Married & 278 & 45.5 \\
& Widowed & 29 & 5 \\
& Undefined & 16 & 3 \\
\hline Educational Attainment & Elementary Undergrad & 12 & 2 \\
& Elementary Graduate & 39 & 7 \\
& High School Undergrad & 49 & 8 \\
& High School Graduate & 127 & 21 \\
& Tertiary Undergraduate & 166 & 28 \\
& Tertiary Graduate & 178 & 30 \\
& Undefined & 29 & 5 \\
\hline Type of Employer & Self & 181 & 30 \\
& Government & 63 & 11 \\
& Private & 61 & 10 \\
& Retired & 25 & 4 \\
& Unemployed & 237 & 40 \\
& Undefined & 33 & 6 \\
\hline Years of Residency & $<10$ years & 49 & 8 \\
& $>10$ years & 137 & 43 \\
& Since birth & 389 & 4 \\
\hline & Undefined & 25 &
\end{tabular}




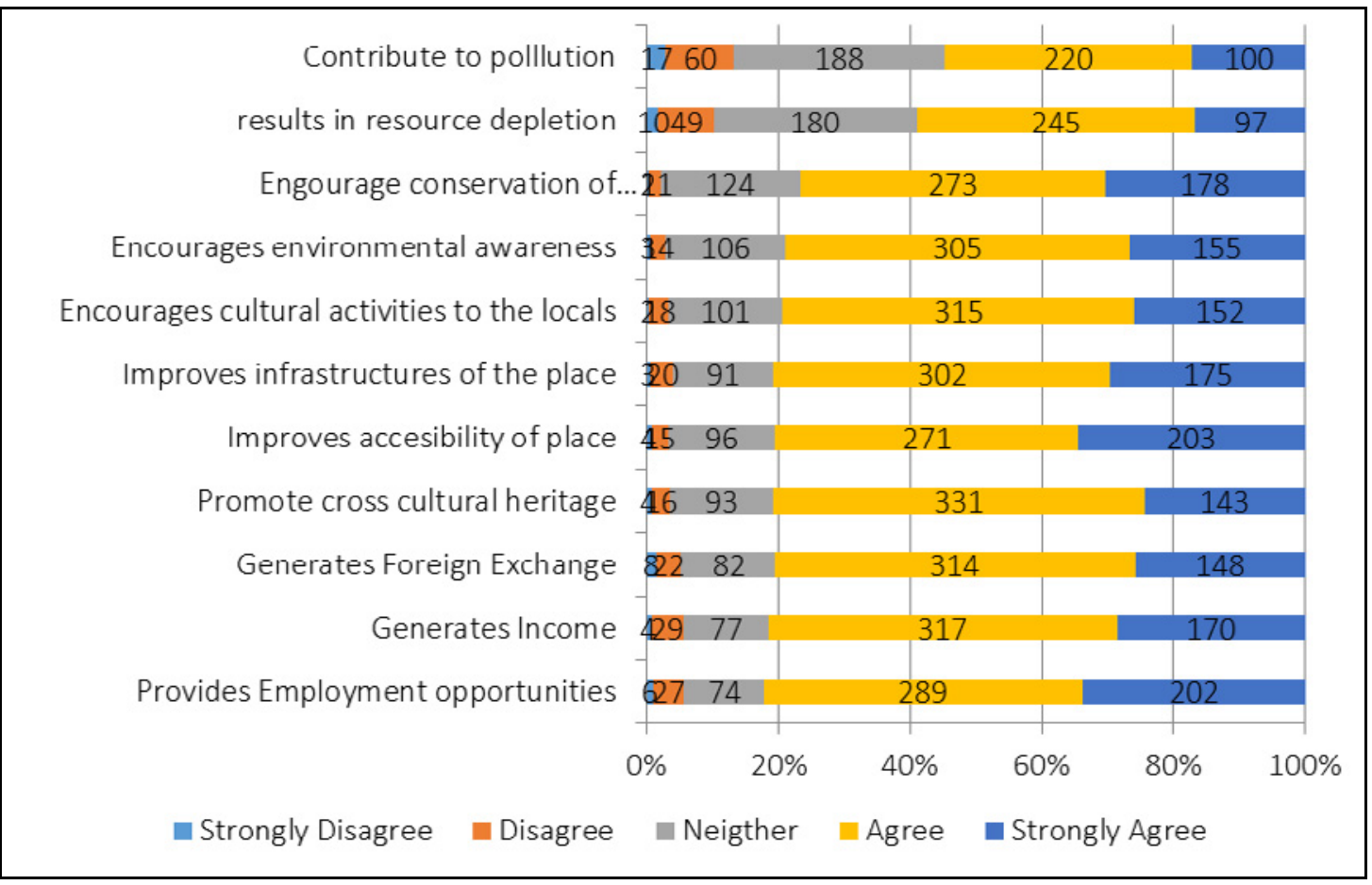

Figure 2. Perception of the Locals Towards Tourism Development

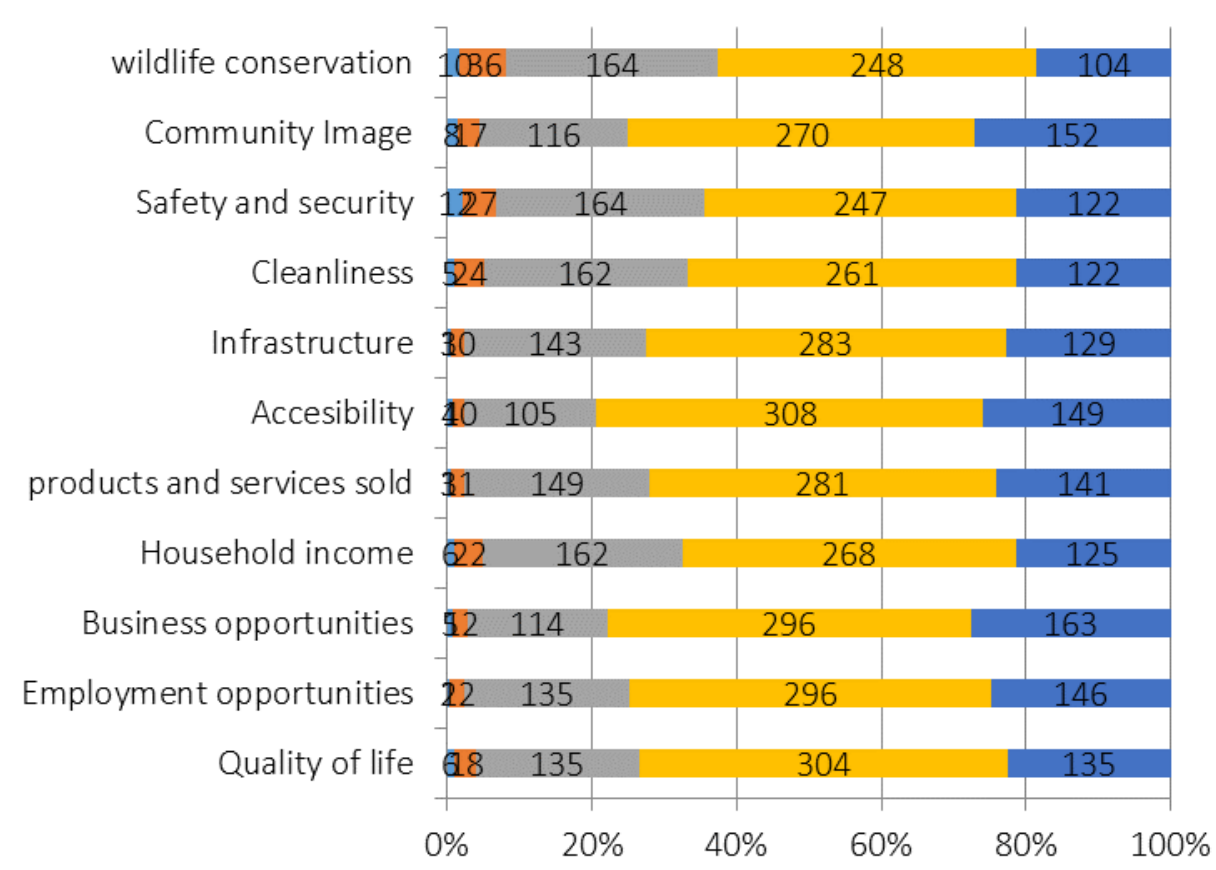

Much worse $\square$ somewhat worse $\square$ about the same $\square$ somewhat better $\square$ much better

Figure 3. Impacts of Tourism Industry and Developments for the past five (5) years. 


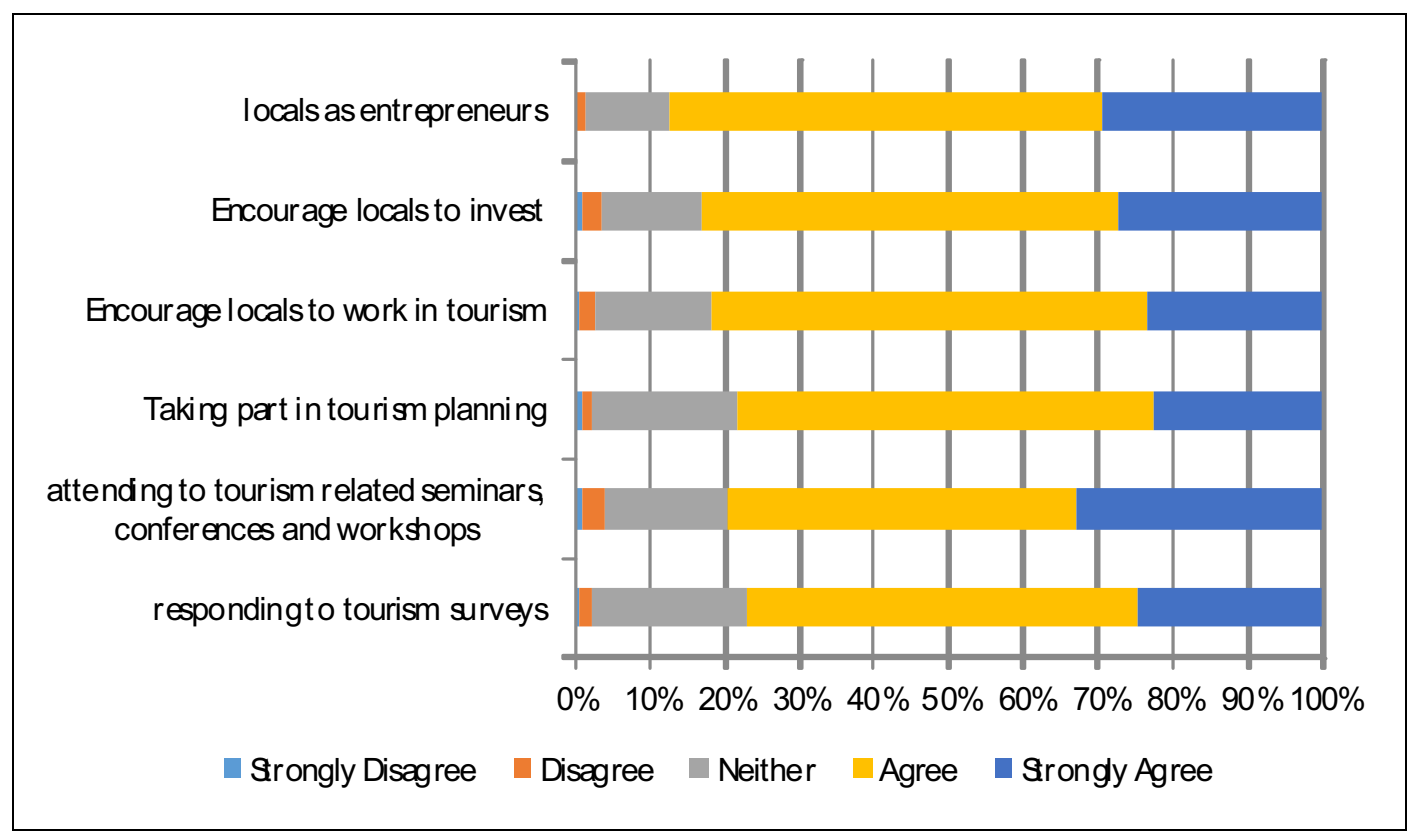

Figure 4. Means of Involving the Locals in the Tourism Industry and Development

\subsection{Mann-Whitney and Kruskal Wallis Test}

To be able to determine whether there is an equal/unequal distribution of locals perception on various categories of socio demographic aspect, Mann-Whitney analysis and Kruskal Wallis test were performed. Table 2 would show that all items listed down except two, has the same distribution among both genders. These two that identifies itself has varied perception across genders are the environmental conservation and being involved in tourism planning

Majority of the statements on perceptions, impacts, means of involving of the locals, the locals' role and agencies who should be involved in tourism planning and development are significantly related on the locals perceived involvement on tourism development.

While, the perception of locals based on how long they stayed in the community was also evaluated whether there is a difference. Test was made using Kruskal-Wallis. It shows that various perceptions are not significantly related to their years of residence except for foreign exchange, resource depletion, and accessibility of the place, pollution, natural resources, encouraging locals to invest and involvement of the LGU.

Table 2. Analysis on the perception of locals on tourism by gender, involvement of the locals and years of residence

\begin{tabular}{|l|c|c|c|}
\hline Perception on Tourism & Gender & $\begin{array}{c}\text { Involvement of } \\
\text { the Locals } \\
\text { Mann-Whitney } \\
\text { Test } \\
p \text {-value }\end{array}$ & $\begin{array}{c}\text { Years of } \\
\text { Residence } \\
\text { Kruskal-Wallis } \\
\text { Test } \\
p \text {-value }\end{array}$ \\
\hline $\begin{array}{l}\text { Tourism provides employment } \\
\text { Test } \\
\text { opportunities }\end{array}$ & 0.514 & $\mathbf{0 . 0 0 0 *}$ & 0.595 \\
\hline Tourism generates income & 0.853 & $\mathbf{0 . 0 0 0 *}$ & 0.062 \\
\hline
\end{tabular}




\begin{tabular}{|c|c|c|c|}
\hline Tourism promotes cross-cultural exchange & 0.429 & $0.000 *$ & 0.451 \\
\hline Tourism generates foreign exchange. & 0.135 & 0.000* & 0.039* \\
\hline $\begin{array}{l}\text { Tourism encourages cultural activities to } \\
\text { the locals. }\end{array}$ & 0.376 & $0.000 *$ & 0.213 \\
\hline $\begin{array}{l}\text { Tourism encourages conservation of } \\
\text { archeological and historical sites. }\end{array}$ & $0.005 *$ & 0.005* & 0.132 \\
\hline $\begin{array}{l}\text { Tourism encourages environmental } \\
\text { awareness. }\end{array}$ & 0.141 & 0.003* & 0.150 \\
\hline Tourism results in resource depletion. & 0.433 & 0.074 & 0.028* \\
\hline Tourism contributes to pollution. & 0.865 & 0.969 & 0.065 \\
\hline $\begin{array}{l}\text { Tourism improves the accessibility of the } \\
\text { place. }\end{array}$ & 0.098 & 0.199 & 0.011* \\
\hline $\begin{array}{l}\text { Tourism improves the infrastructure of the } \\
\text { place. }\end{array}$ & 0.161 & 0.051 & 0.336 \\
\hline \multirow[t]{2}{*}{$\begin{array}{l}\text { Impact of Tourism Development to the } \\
\text { Locals }\end{array}$} & & $\begin{array}{l}\text { Involvement of } \\
\text { the Locals }\end{array}$ & $\begin{array}{c}\text { Years of } \\
\text { Residence }\end{array}$ \\
\hline & $\begin{array}{c}\text { Mann-Whitney } \\
\text { Test } \\
\text { p-value }\end{array}$ & $\begin{array}{l}\text { Mann-Whitney } \\
\text { Test } \\
\text { p-value }\end{array}$ & $\begin{array}{c}\text { Kruskal-Wallis } \\
\text { Test } \\
\text { p-value }\end{array}$ \\
\hline Quality of life of the locals & 0.619 & 0.000* & 0.140 \\
\hline Employment & 0.484 & 0.000* & 0.142 \\
\hline Business Opportunities for the locals & 0.706 & $0.000 *$ & 0.673 \\
\hline Household income of the locals & 0.818 & 0.000* & 0.150 \\
\hline $\begin{array}{l}\text { Products and services sold and offered by } \\
\text { the business establishment in the } \\
\text { community }\end{array}$ & 0.146 & $0.000 *$ & 0.287 \\
\hline $\begin{array}{l}\text { Accessibility (transportation and } \\
\text { communication) }\end{array}$ & 0.874 & 0.000* & 0.618 \\
\hline Infrastructures & 0.463 & 0.070 & 0.209 \\
\hline Cleanliness of the community & 0.758 & $0.027^{*}$ & 0.525 \\
\hline Safety and Security & 0.207 & $0.000 *$ & 0.447 \\
\hline Community Image & 0.925 & $0.000 *$ & 0.326 \\
\hline Wildlife Conservation & 0.160 & 0.000* & 0.335 \\
\hline Pollution & 0.096 & 0.204 & 0.038* \\
\hline Natural Resources & 0.607 & $0.000 *$ & 0.000* \\
\hline
\end{tabular}




\begin{tabular}{|c|c|c|c|}
\hline Foreign Exchange & 0.136 & $.0000 *$ & 0.004 \\
\hline $\begin{array}{l}\text { Perception on the Means of Involving } \\
\text { Local People in Tourism Development }\end{array}$ & $\begin{array}{c}\text { Gender } \\
\text { Mann-Whitney } \\
\text { Test } \\
\text { p-value }\end{array}$ & $\begin{array}{l}\text { Involvement of } \\
\text { the Locals } \\
\text { Mann-Whitney } \\
\text { Test } \\
\text { p-value }\end{array}$ & $\begin{array}{c}\begin{array}{c}\text { Years of } \\
\text { Residence }\end{array} \\
\text { Kruskal-Wallis } \\
\text { Test } \\
p \text {-value }\end{array}$ \\
\hline $\begin{array}{l}\text { Encouraging locals to invest in tourism } \\
\text { industry }\end{array}$ & 0.522 & 0.000* & $0.025 *$ \\
\hline $\begin{array}{l}\text { Encouraging locals to work for the } \\
\text { tourism industry }\end{array}$ & 0.290 & 0.000* & 0.356 \\
\hline $\begin{array}{l}\text { Taking part in tourism planning for } \\
\text { developments }\end{array}$ & 0.014 & 0.000* & 0.240 \\
\hline Responding to tourism surveys & 0.188 & 0.003* & 0.986 \\
\hline $\begin{array}{l}\text { Attending to tourism related seminars, } \\
\text { conferences, workshops. }\end{array}$ & 0.137 & $0.000 *$ & 0.132 \\
\hline $\begin{array}{l}\text { Perception on the Appropriate Role of } \\
\text { the Local People in Tourism } \\
\text { Development }\end{array}$ & $\begin{array}{c}\text { Gender } \\
\text { Mann-Whitney } \\
\text { Test } \\
\text { p-value }\end{array}$ & $\begin{array}{c}\text { Involvement of } \\
\text { the Locals } \\
\text { Mann-Whitney } \\
\text { Test } \\
\text { p-value }\end{array}$ & $\begin{array}{c}\begin{array}{c}\text { Years of } \\
\text { Residence }\end{array} \\
\text { Kruskal-Wallis } \\
\text { Test } \\
\text { p-value }\end{array}$ \\
\hline Locals as entrepreneurs & 0.507 & 0.013* & 0.265 \\
\hline Locals as workers in tourism industry & 0.150 & $0.000 *$ & 0.436 \\
\hline Local as part of the tourism planning & 0.825 & 0.007* & 0.245 \\
\hline $\begin{array}{c}\text { Perception of the Locals on Who Should } \\
\text { Make the Plan for the Tourism } \\
\text { Development }\end{array}$ & $\begin{array}{c}\text { Gender } \\
\begin{array}{c}\text { Mann-Whitney } \\
\text { Test }\end{array} \\
\text { p-value }\end{array}$ & $\begin{array}{l}\text { Involvement of } \\
\text { the Locals } \\
\text { Mann-Whitney } \\
\text { Test } \\
\text { p-value }\end{array}$ & $\begin{array}{c}\begin{array}{c}\text { Years of } \\
\text { Residence }\end{array} \\
\text { Kruskal-Wallis } \\
\text { Test } \\
p \text {-value }\end{array}$ \\
\hline Department of Tourism & 0.541 & 0.000* & 0.918 \\
\hline Provincial Government of Ilocos Norte & 0.177 & 0.001* & 0.372 \\
\hline Local Government Unit (LGU) & 0.082 & $0.000 *$ & 0.005* \\
\hline Private Sector & 0.213 & 0.009* & 0.075 \\
\hline
\end{tabular}




\section{ICTR}

\section{Summary and Conclusion}

The study clearly shows that most locals has a positive impression on tourism development on all aspects of socio-cultural, economic, environmental impacts. It there show that the locals want to participate the development of the community not only because of group interest but as individuals as well. Most would want to uplift their lives as they could see the tourism development as an inflow of revenue to the locality and they want to be involved either as a worker or an investor. There is however, as small portion of the community that must not be ignored which says that pollution and cleanliness in an increasing concern on tourism development. This should be addressed alongside economic development to be able to have a sustainable livelihood.

With regards to gender perception on the issues, both genders have similar impressions except on aspects of tourism planning and environmental conservation. The variation on the perception of involved locals on various is very varied. However, residents have varying perceptions on various issues depending on years of stay. Most of them have the same perception except foreign exchange, natural resources, and locals to invest.

\section{References}

1 M. Muganda, Community involvement and participation in tourism Development in Tanzania. Barbarani Village: unpublished (2009)

2 Tosun, Towards a typology of Community Participation in the Tourism Development Process. Tipology of community participation, vol. 10, 2, 113 (1991)

3 Tosun Limits to community participation in the tourism development process in developing countries. Bilkert, Ankara, Turkey. Elsevier Science Ltd (2000)

4 P. E. Murphy, Tourism management in host communities. The Canadian Geographer, Vol. 24 (10), pp. 1 (1980)

5 P. Murphy \& A.E. Murphy, Strategic management for tourism communities. Clevedon: Channel View Publications (2004)

6 B. Donoghue, A sustainable future for tourism. London: Visit Britain, online at http://www.visitbritain.com/en/Images/Review\%20Sustainability\%20chapter\%20final\%202008 t cm12-153751.pdf, (accessed 9 June 2010) 